\title{
Texture analysis can be used to improve skin sonography quantification capacities
}

\author{
A análise da textura pode ser usada para melhorar as capacidades de quantificação da \\ sonografia da pele
}

\author{
Ana S. Macedo ${ }^{1}$, Henrique Silva ${ }^{1,2}$, Luís Monteiro Rodrigues ${ }^{1,2}$ \\ ${ }^{1} \mathrm{CBiOS}$ (Research Center for Biosciences and Health Technologies), Universidade Lusófona, de Humanidades e \\ Tecnologias, Lisboa, Portugal. \\ ${ }^{2}$ Pharmacol. Sc Depart, U Lisboa, Faculty of Pharmacy, Lisboa, Portugal \\ E-mail: ana.macedo@ulusofona.pt
}

\begin{abstract}
Image interpretation of sonograms is a difficult process since it largely depends on the observer's experience and is the limited by image resolution of commercial scanners. Texture analysis offers a range of analysis tools that assess the spatial variation and distribution of gray levels within a given image and translates them into quantitative parameters. We compared non-treated skin, hydrated, and erythema. Texture analysis parameters (entropy, contrast, correlation, energy, homogeneity) were calculated from the epidermis, dermis, and hypodermis selected regions of interest. Entropy, contrast and homogeneity were higher in the more echogenic epidermis, while correlation and energy were higher for the more homogenous dermis. The echo, entropy, contrast and correlation were found to be consistently lower on both layers of the hydrated skin and erythema, while energy was higher. These results suggest that texture analysis is useful to quantitatively describe the differences in skin layers based on their echogenic profile.
\end{abstract}

Keywords: texture analysis, ultrasonography, skin, hydration, erythema

\begin{abstract}
Resumo
A interpretação de imagens de sonogramas é um processo difícil, pois depende muito da experiência do observador e é limitado pela resolução de imagem dos scanners comerciais. A análise de textura oferece uma variedade de ferramentas de análise que avaliam a variação espacial e a distribuição dos níveis de cinza dentro de uma determinada imagem e as traduz em parâmetros quantitativos. Comparamos pele não tratada, hidratada e com eritema. Os parâmetros de análise de textura (entropia, contraste, correlação, energia, homogeneidade) foram calculados a partir das regiões de interesse selecionadas da epiderme, da derme e hipoderme. Entropia, contraste e homogeneidade foram maiores na epiderme mais ecogénica, enquanto correlação e energia foram maiores para a derme mais homogénea. $\mathrm{O}$ eco, entropia, contraste e correlação foram consistentemente menores em ambas as camadas da pele hidratada e eritema, enquanto a energia foi maior. Estes resultados sugerem que a análise de textura é útil para descrever quantitativamente as diferenças nas camadas da pele com base no seu perfil ecogénico.
\end{abstract}

Palavras-chave: análise de textura, ultrassonografia, pele, hidratação, eritema 


\section{Introduction}

Ultrasonography was first introduced in 1979 by Alexander Miller as a non-invasive imaging technique to assess skin thickness $[1,2]$. High resolution sonography was introduced in the 1980s and has been the most used in vivo imaging technique for medical diagnosis for the last 50 years [3]. Commercially available scanners have transducers that operate in the $16-100 \mathrm{MHz}$ frequencies, which limits image resolution and, therefore, image analysis [3-5]. Ultrasonography has been used to assess many skin diseases, including dermatitis [6], hypersensitivity reactions [7], edema [8], psoriasis [9], [10], skin tumours [5], [11], [12], and wound healing [13]. However, the image interpretation is a difficult process since it largely depends on the observer's experience and is further complicated by the limited image resolution of commercial scanners. Image analysis and intensity quantification is restricted, ultimately leading to poor applicability in the clinical diagnostics.

Texture analysis (TA) offers a range of analysis tools that assess the spatial variation and distribution of gray levels within a given image and translate them into quantitative parameters. The gray-level co-occurrence matrix (GLCM) generated by the examination of the spatial relationship of pixels is used to characterize how often pairs of pixels that have a set of specific values and spatial relationship occur in an image. The matrix is then used to extract statistical parameters, such as correlation, mean, root mean square [14]. TA has been successfully employed in the past for the analysis of Xray images of trabecular bone [15], magnetic resonance images [16], [17], but not for sonograms as yet.

Our aim was to explore TA tools to quantify and compare changes in the epidermis, dermis, hypodermis in intact, hydrated skin and erythema and offer a potential strategy to obtain semi-quantifiable parameters from ultrasonography images.

\section{Materials and Methods}

Images from the volar forearm were taken using a 20$\mathrm{MHz}$ ultrasonography (Dermascan C, Cortex Technology, Denmark) in six healthy volunteers (aged 25-60) of both sexes, selected after informed consent. Nontreated skin was compared to hydrated skin with a 5\% solution of propylene glycol (Sigma-Aldrich Quimica, Sintra, Portugal) under occlusion for 24 hours, and ery-

\section{Introdução}

A ultrassonografia foi introduzida pela primeira vez em 1979 por Alexander Miller como uma técnica de imagem não invasiva para avaliar a espessura da pele [1], [2]. A ultrassonografia de alta resolução foi introduzida na década de 1980 e tem sido a técnica de imagem in vivo mais utilizada para o diagnóstico médico nos últimos 50 anos [3]. Os scanners comercialmente disponíveis possuem transdutores que operam nas frequências de 16-100 MHz, o que limita a resolução da imagem e, portanto, a análise de imagem [3-5]. A ultrassonografia tem sido usada para avaliar muitas doenças de pele, incluindo dermatite [6], reações de hipersensibilidade [7], edema [8], psoríase [9], [10], tumores de pele [5], [11], [12], e cicatrização de feridas [13]. No entanto, a interpretação da imagem é um processo difícil, pois depende muito da experiência do observador e é ainda mais complicada pela resolução limitada da imagem dos scanners comerciais. A análise de imagens e a quantificação da intensidade são restritas, o que leva a uma baixa aplicabilidade nos diagnósticos clínicos.

A análise de textura (TA) oferece uma gama de ferramentas de análise que avaliam a variação espacial e a distribuição dos níveis de cinza dentro de uma determinada imagem e as traduz em parâmetros quantitativos. A matriz de coocorrência em nível de cinza (GLCM) gerada pelo exame da relação espacial dos pixels foi utilizada para caracterizar a frequência com que pares de pixels, que possuem um conjunto de valores específicos e relação espacial, ocorrem em uma imagem. A matriz foi então usada para extrair parâmetros estatísticos, como correlação, média, raiz quadrada média [14]. A TA tem sido utilizad com sucesso no passado para a análise de imagens radiográficas do osso trabecular [15], imagens de ressonância magnética [16], [17], mas não para ultrassonografias até o momento.

O objetivo deste trabalho foi explorar ferramentas TA para quantificar e comparar as alterações na epiderme, derme, hipoderme na pele intacta, hidratada e eritema e oferecer uma estratégia potencial para obter parâmetros semi-quantificáveis de imagens de ultrassonografia.

\section{Materiais e Métodos}

As imagens do antebraço volar foram feitas com ultrassonografia de $20 \mathrm{MHz}$ (Dermascan C, Cortex Technology, Dinamarca) em 6 voluntários saudáveis (25-60 anos) de ambos os sexos, selecionados após o consentimento informado. A pele não tratada foi comparada à pele hidratada com uma solução a $5 \%$ de propilenoglicol (Sigma-Aldrich Química, Sintra, Portugal) sob 
thema caused by $0.1 \mathrm{M}$ methyl nicotinate $(99 \%$, SigmaAldrich Quimica, Sintra, Portugal) applied for 1 minute in a damped filter paper. All procedures complied with the principles of the Helsinki declaration and subsequent amendments [18]. The probe was placed on the skin in a fixed standard position, with the echo recorded at a velocity of $1580 \mathrm{~m} / \mathrm{s}$, to obtain a two dimensionalimage (Figure 1). The color image was converted to a grey scale image for further analysis. TA parameters (entropy, contrast, correlation, energy, homogeneity) were calculated from the epidermis, dermis, and hypodermis selected regions of interest.

Several texture analysis (TA) parameters (entropy, contrast, correlation, energy, homogeneity) were calculated for each skin layer from the grayscale image.

Descriptive and non-parametric statistics were applied using SPSS 21.0 (IBM, USA). The Wilcoxon signedrank test was also used for paired samples comparisons. A confidence level of $95 \%(p<0.05)$ was adopted. oclusão por 24 horas, e eritema causado por metil nicotinato 0,1M (99\%, Sigma-Aldrich Quimica, Sintra, Portugal) aplicado por $1 \mathrm{~min}$ em papel de filtro. Todos os procedimentos cumpriram os princípios da declaração de Helsínquia e alterações subsequentes [18]. A sonda foi colocada na pele em uma posição padrão fixa, com o eco gravado a uma velocidade de $1580 \mathrm{~m} / \mathrm{s}$, para obter uma imagem bidimensional (Figura 1). A imagem colorida foi convertida numa imagem em escala de cinza para análise posterior. Os parâmetros TA (entropia, contraste, correlação, energia, homogeneidade) foram calculados a partir das regiões selecionadas de interesse da epiderme, derme e hipoderme. Vários parâmetros de análise de textura (TA) (entropia, contraste, correlação, energia, homogeneidade) foram calculados para cada camada de pele a partir da imagem em escala de cinza. Estatísticas descritivas e não paramétricas foram aplicadas no SPSS 21.0 (IBM, EUA). O teste dos postos sinalizados de Wilcoxon também foi usado para comparações de amostras pareadas. Um nível de confiança de $95 \%$ ( $p<0,05)$ foi adotado.

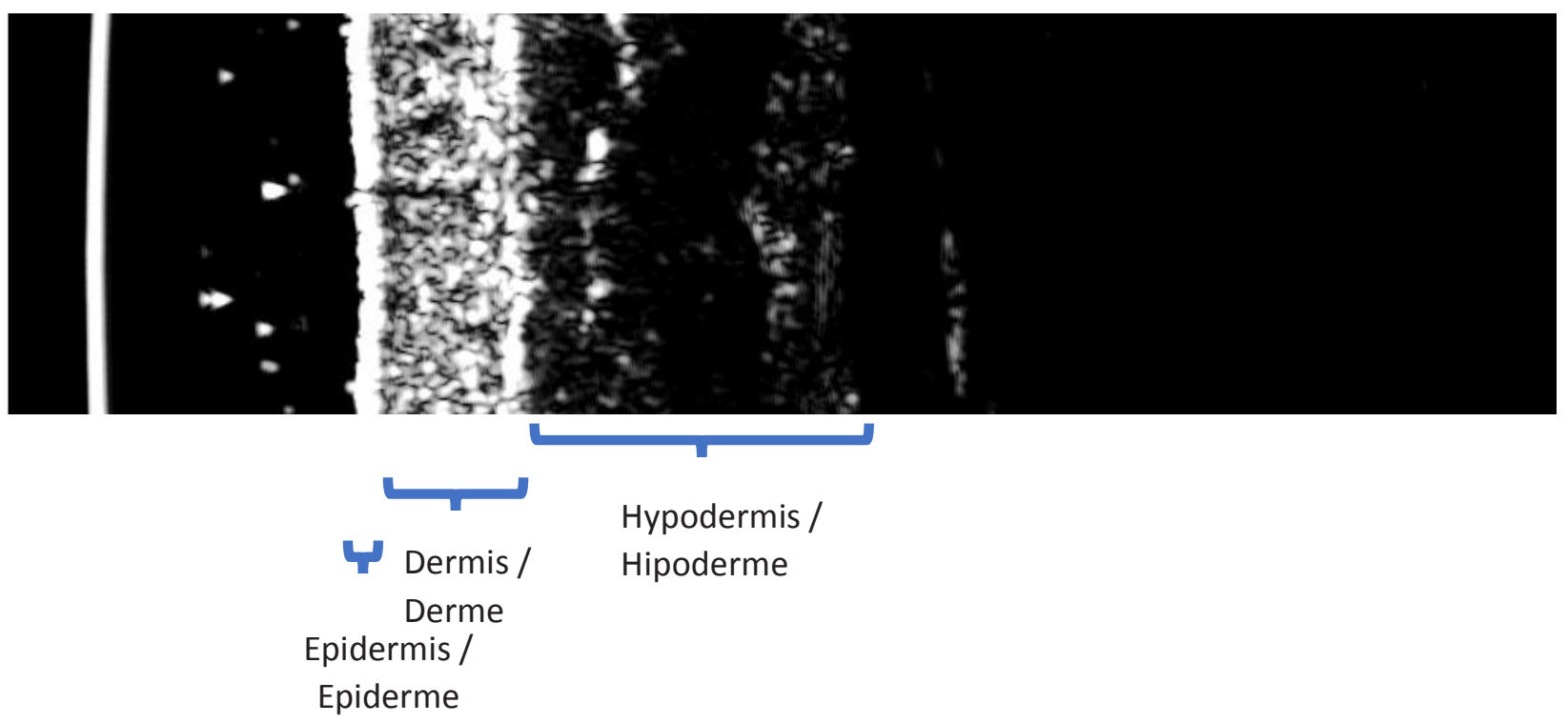

Figure 1/Figura 1 - Grayscale image of the skin scan (female volunteer, 58 years old, methyl nicotinate test). Each skin layer is identified.

Imagem em tons de cinzento de um scan da pele (voluntário feminino, 58 anos, teste do metilnocotinato). As camadas da pele encontram-se identificadas na imagem.

\section{Results and Discussion}

TA parameters used to characterize grayscale images were entropy, contrast, correlation, energy, and homogeneity. The grayscale sonograms were compared for each volunteer with three different skin treatments (Figure 2). The differences in the echo intensity can be observed when the non-treated skin (Figure 2A), hydrated

\section{Resultados e Discussão}

Os parâmetros TA usados para caracterizar as imagens em escala de cinza foram entropia, contraste, correlação, energia e homogeneidade. Os sonogramas em escala de cinza foram comparados para cada voluntário com três diferentes tratamentos de pele (Figura 2). As diferenças na intensidade do eco podem ser observadas 
(Figure 2B), and skin with erythema (Figure 2C) are observed for the same volunteer. The epidermis is a poor echogenic region of the skin, however, as a echogenic translucent band resulting from the echo entrance overlaps with the epidermis, creating an image artefact [3], [19], [20]. The calculated intensity presented in Table I is approximately 0.5 and is similar to the intensity of the dermis. As expected, the calculated intensity in the hypodermis is lower (approximately 0.04 ) compared to the other skin layers due to high volume of fluids existing in the hypodermis that result in poor echo [21]. No statistically significant differences were found in the echo intensity between the various layers of the skin in the three treatments (Table I). The algorithm used to analyse intensity of echo in each skin layer allows direct comparison of the echo intensity in each skin layer, but it does not determine the boundaries of each layer.

Entropy is the measure of randomness and can be used to characterize the texture of the input image. The intensity contrast between a pixel and its neighbor over the whole image is a measured by Contrast. By determining the contrast, it is possible to calculate the correlation between adjacent pixels over the whole image. Energy returns the sum of squared elements in the GLCM, and homogeneity is the measure of the closeness of the distribution of elements in the GLCM to the GLCM diagonal. em pele não tratada (Figura 2A), hidratada (Figura 2 B) e pele com eritema (Figura 2C) para o mesmo voluntário. A epiderme é uma região pobre em eco da pele, no entanto, uma faixa translúcida ecogénica resultante da entrada do eco sobrepõe-se à epiderme, criando um artefacto de imagem [3], [19], [20]. A intensidade calculada apresentada na Tabela I é de aproximadamente 0,5 e é semelhante à intensidade da derme. Como esperado, a intensidade calculada na hipoderme é menor (aproximadamente 0,04 ) em comparação com as outras camadas da pele, devido ao alto volume de fluidos existentes na hipoderme, que resulta num eco pobre [21]. Não foram encontradas diferenças estatisticamente significantes na intensidade do eco entre as várias camadas da pele nos três tratamentos (Tabela I). O algoritmo usado para analisar a intensidade do eco permite a comparação direta da intensidade do eco em cada camada da pele, mas não determina os limites de cada camada. A entropia é a medida de aleatoriedade e pode ser usada para caracterizar a textura da imagem de entrada. A variação de intensidade entre um pixel e seu vizinho sobre toda a imagem é medido pelo contraste. Ao determinar o contraste, é possível calcular a correlação entre os pixels adjacentes em toda a imagem. A energia retorna a soma dos elementos quadrados no GLCM, e a homogeneidade é a medida da proximidade da distribuição dos elementos no GLCM à diagonal do GLCM.
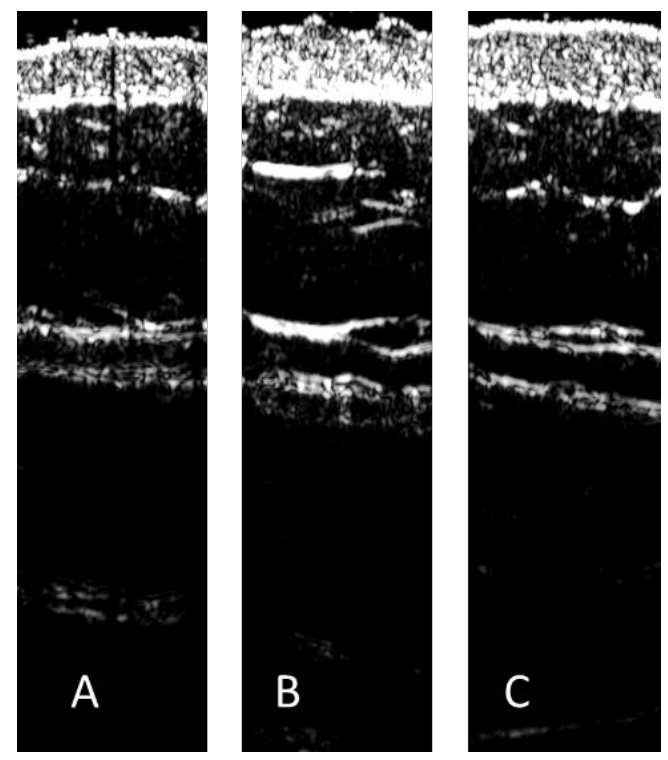

Figure 2/Figura 2 - Sonograms from non-treated skin (A), hydrated skin with $5 \%$ propylene glycol (B), and erythema caused by methylnicotinate (C) $(\mathrm{n}=1) /$ Sonogramas da pele não tratada $(\mathrm{A})$, hidratada com $5 \%$ de propilenoglicol e eritema causado por metilnicotinato $(\mathrm{C})(\mathrm{n}=1)$. 
Table 1/Tabela 1 - Summary of the echo intensity analysed by GLCM in each skin layer in nontreated skin, hydrated skin, and skin with erythema. $(n=6$, mean values and standard deviation are represented)/ Sumário da intensidade do eco analisado por GLCM para camada de pele em pele não tratada, pele hidratada e pele com eritema. $(n=6$, valores médios e desvio padrão estão representados)

\section{Treatment/Tratamento}

\begin{tabular}{lccc}
\hline $\begin{array}{c}\text { Skin depth/ } \\
\text { Profundidade da } \\
\text { pele }\end{array}$ & $\begin{array}{c}\text { Non-treated/ } \\
\text { Não tratada }\end{array}$ & $\begin{array}{c}\text { Hydrated/ } \\
\text { Hidratada }\end{array}$ & $\begin{array}{c}\text { Erythema/ } \\
\text { Eritema }\end{array}$ \\
\hline Epidermis & $0.45 \pm 0.05$ & $0.38 \pm 0.19$ & $0.46 \pm 0.09$ \\
p value & - & 0.686 & 0.892 \\
Dermis & $0.47 \pm 0.11$ & $0.52 \pm 0.09$ & $0.47 \pm 0.14$ \\
p value & - & 0.465 & 0.715 \\
Hypodermis & $0.04 \pm 0.02$ & $0.05 \pm 0.04$ & $0.03 \pm 0.03$ \\
p value & - & 0.854 & 0.197 \\
\hline
\end{tabular}

The analysed entropy (Figure 3) was higher in the dermis for all skin treatments, approximately 7, compared to the epidermis (approximately 3.5) and hypodermis (approximately 5). The higher entropy in the dermis can be explained by the structural heterogenicity of the dermis which contributes to a highly echogenic structure [4], [22], and consequently, to higher entropy compared to the other skin layers. The entropy decreased slightly with the erythema and in the hydrated skin, possibly due to the higher content in extracellular fluid and water, resulting in lower echo [19].

Higher contrast was observed in the epidermis compared to the dermis and hypodermis (Figure 4) due to low echo in these layers, but also due to the presence of the echo entrance band that overlaps with the epidermis, as we have previously suggested. Homogeneity was not affected by the treatments or the skin layers (Figure 5). The hypodermis revealed a higher energy due to high density of pixels, even though the echo was poor.

High correlation in intensity was observed between the pixels, suggesting the algorithm is adequate for the image analysis, with good reproducibility and low variability.
A entropia analisada (Figura 3) foi maior na derme para todos os tratamentos de pele, aproximadamente 7, em comparação com a epiderme (aproximadamente 3,5) e hipoderme (aproximadamente 5). A elevada entropia na derme pode ser explicada pela heterogeneidade estrutural da derme que contribui para uma estrutura altamente ecogénica [4], [22] e, consequentemente, para entropia mais alta em comparação com as outras camadas da pele. A entropia diminuiu ligeiramente com o eritema e na pele hidratada, possivelmente devido ao maior conteúdo no de fluido extracelular e água, que resultaram em menor eco [19]. O contraste foi mais elevado na epiderme comparado à derme e hipoderme (Figura 4) devido ao baixo eco nessas camadas, mas também devido à presença da faixa de entrada do eco que se sobrepõe à epiderme, como sugerimos anteriormente. A homogeneidade não foi afetada pelos tratamentos ou pelas diferenças nas camadas da pele (Figura 5). A hipoderme revelou uma energia mais alta devido à alta densidade de pixels, embora o eco seja baixo. Alta correlação de intensidade foi observada entre os pixels, sugerindo que o algoritmo é adequado para a análise de imagens, com boa reprodutibilidade e baixa variabilidade. 


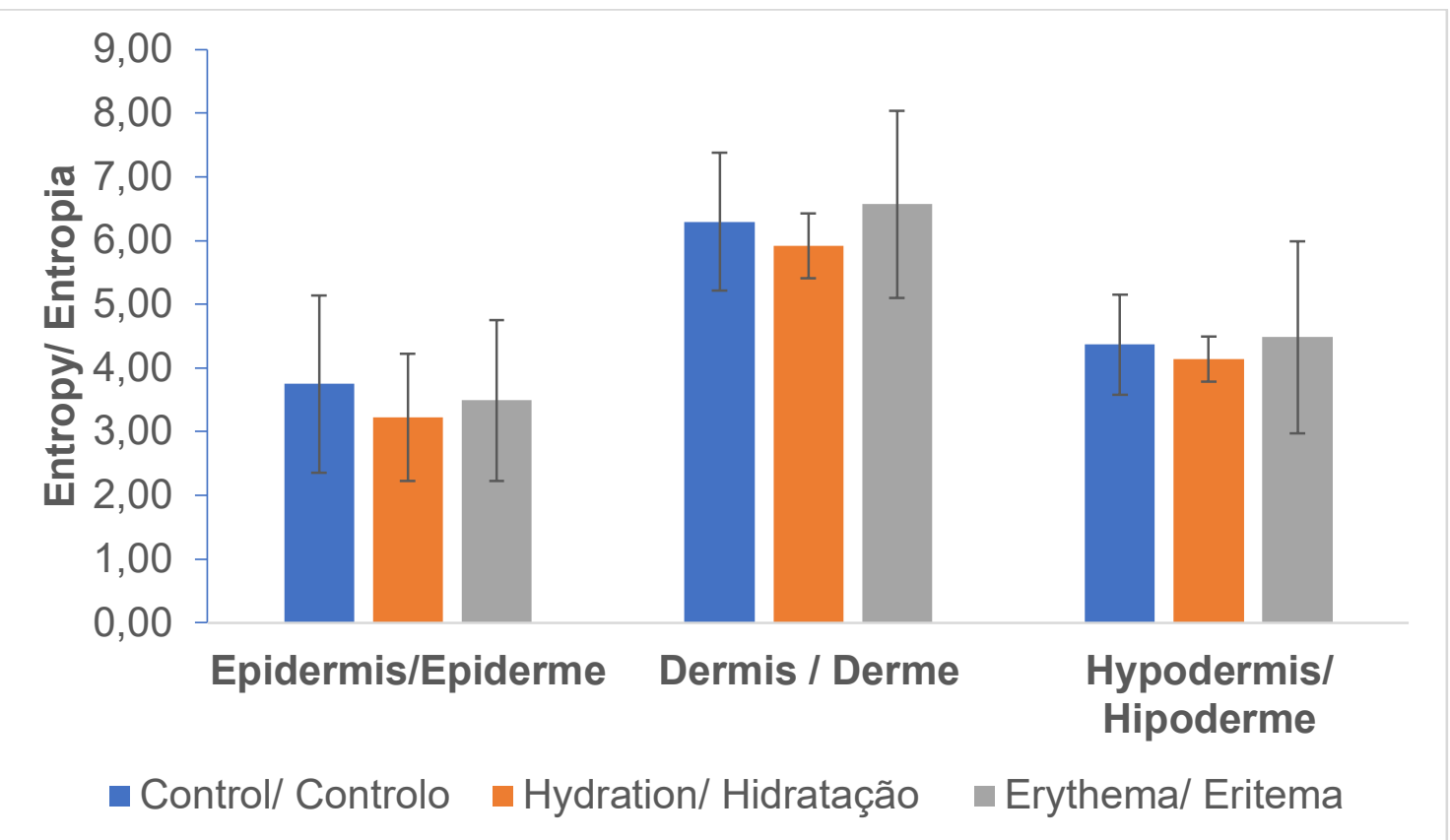

Figure 3/Figura 3 - Entropy analysis of the epidermis, dermis and hypodermis of the non-treated skin, hydrated skin, and erythema (values represent mean $n=6$ and error bars represent standard deviation). Análise de Entropia da epiderme, derme e hipoderme de pele não tratada, pele hidratada e com eritema (são representados valores médios $n=6$ enquanto que as barras de erro representam o desvio padrão)

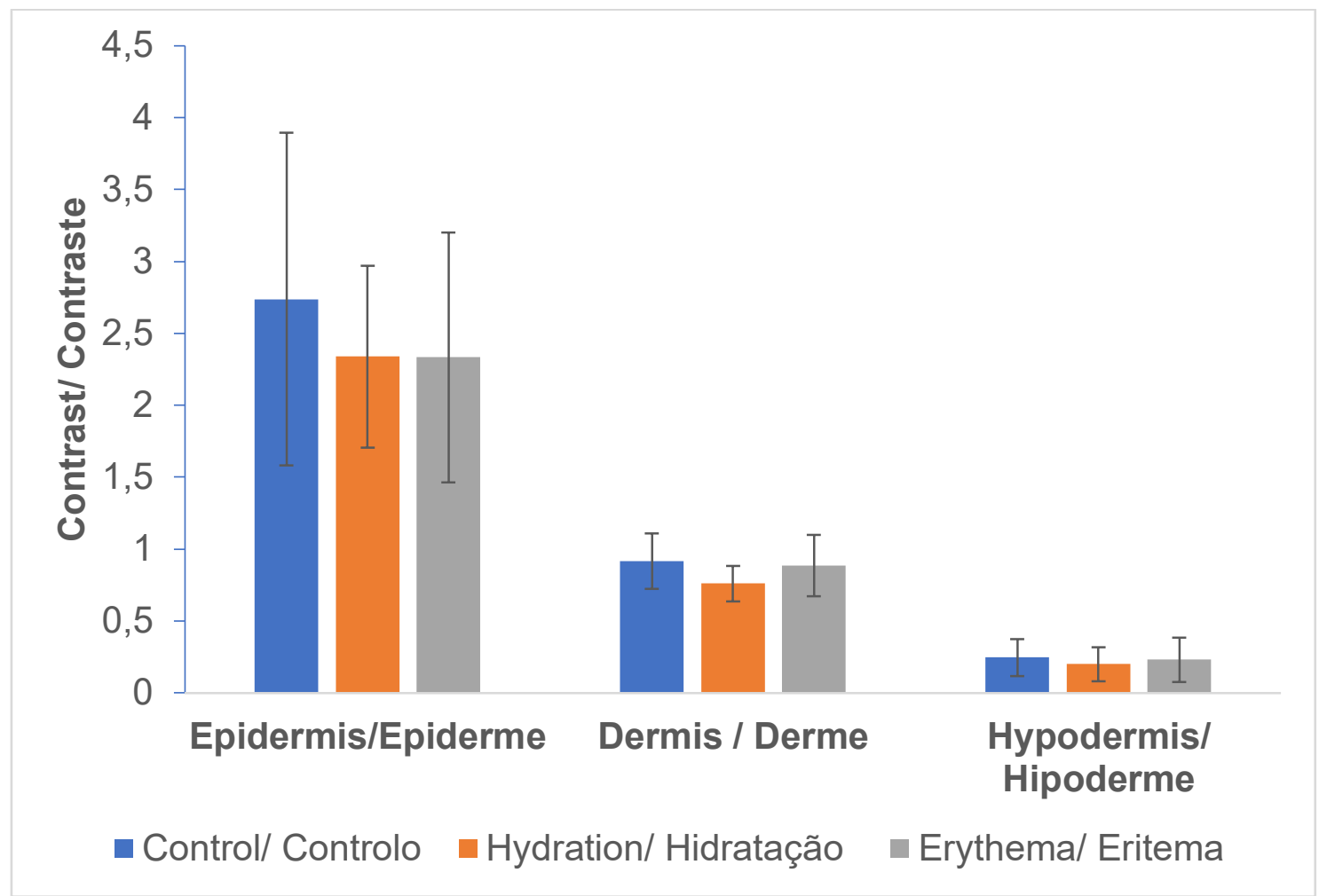

Figure 4/Figura 4 - Contrast analysis of the epidermis, dermis and hypodermis of the non-treated skin, hydrated skin, and erythema (values represent mean $n=6$ and error bars represent standard deviation). Análise de Contraste da epiderme, derme e hipoderme de pele não tratada, pele hidratada e com eritema (são representados valores médios $n=6$ enquanto que as barras de erro representam o desvio padrão) 


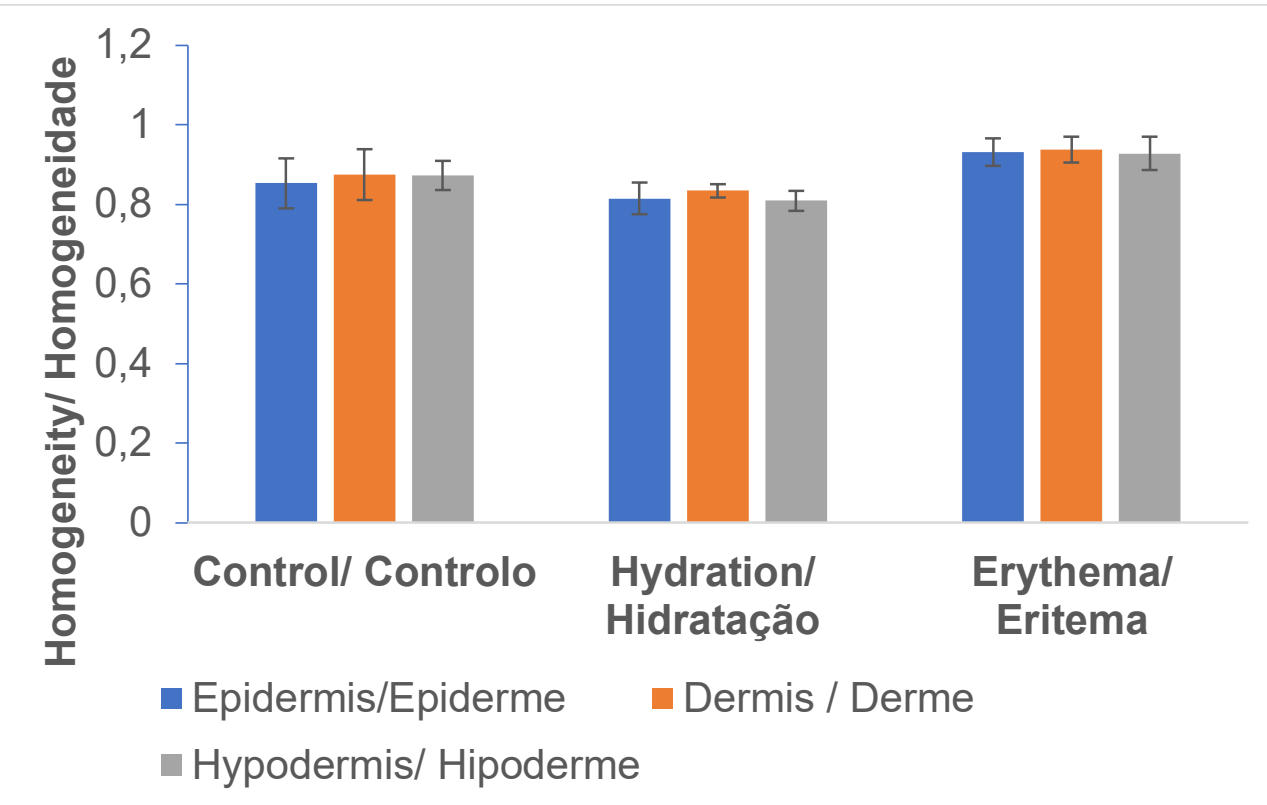

Figure 5/Figura 5 - Homogeneity analysis of the epidermis, dermis and hypodermis of the non-treated skin, hydrated skin, and erythema (values represent mean $n=6$ and error bars represent standard deviation).

Análise de Homogenidade da epiderme, derme e hipoderme de pele não tratada, pele hidratada e com eritema (são representados valores médios $n=6$ enquanto que as barras de erro representam o desvio padrão)

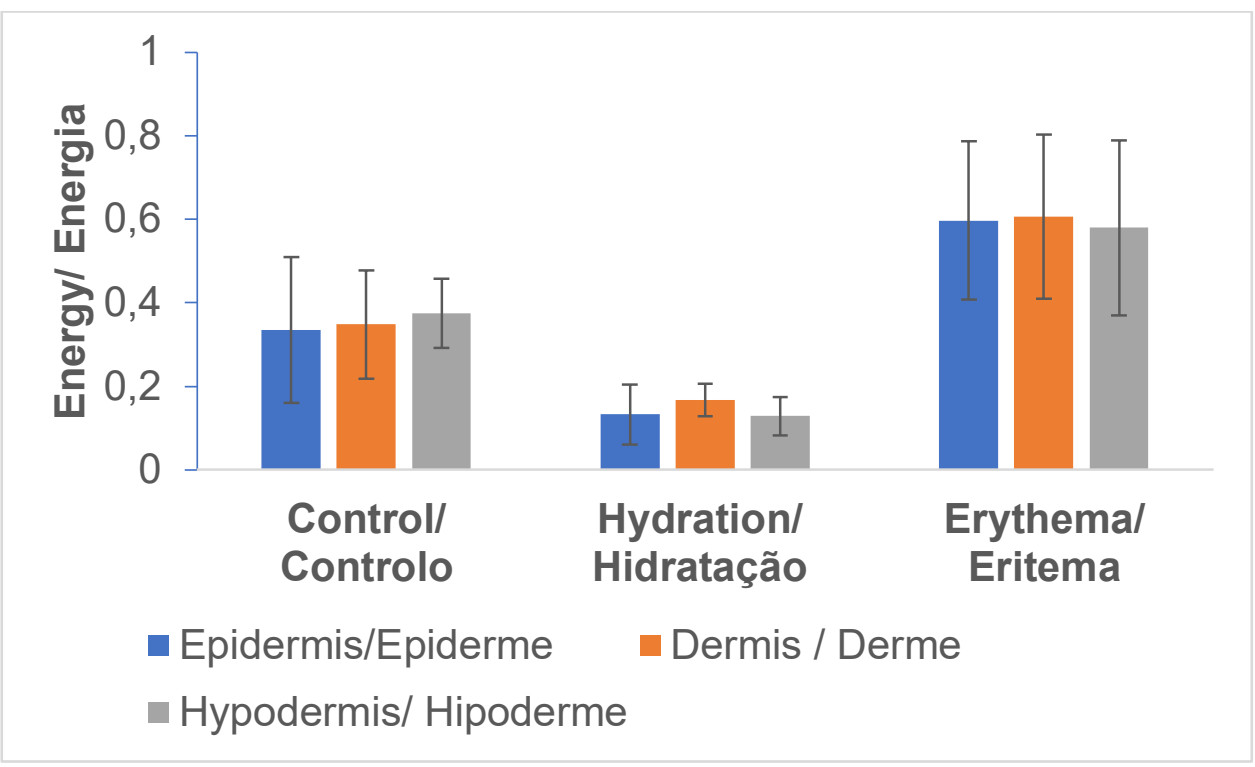

Figure 6/Figura 6 - Energy analysis of the epidermis, dermis and hypodermis of the non-treated skin, hydrated skin, and erythema (values represent mean $n=6$ and error bars represent standard deviation).

Análise de Energia da epiderme, derme e hipoderme de pele não tratada, pele hidratada e com eritema (são representados valores médios $n=6$ enquanto que as barras de erro representam $o$ desvio padrão) 


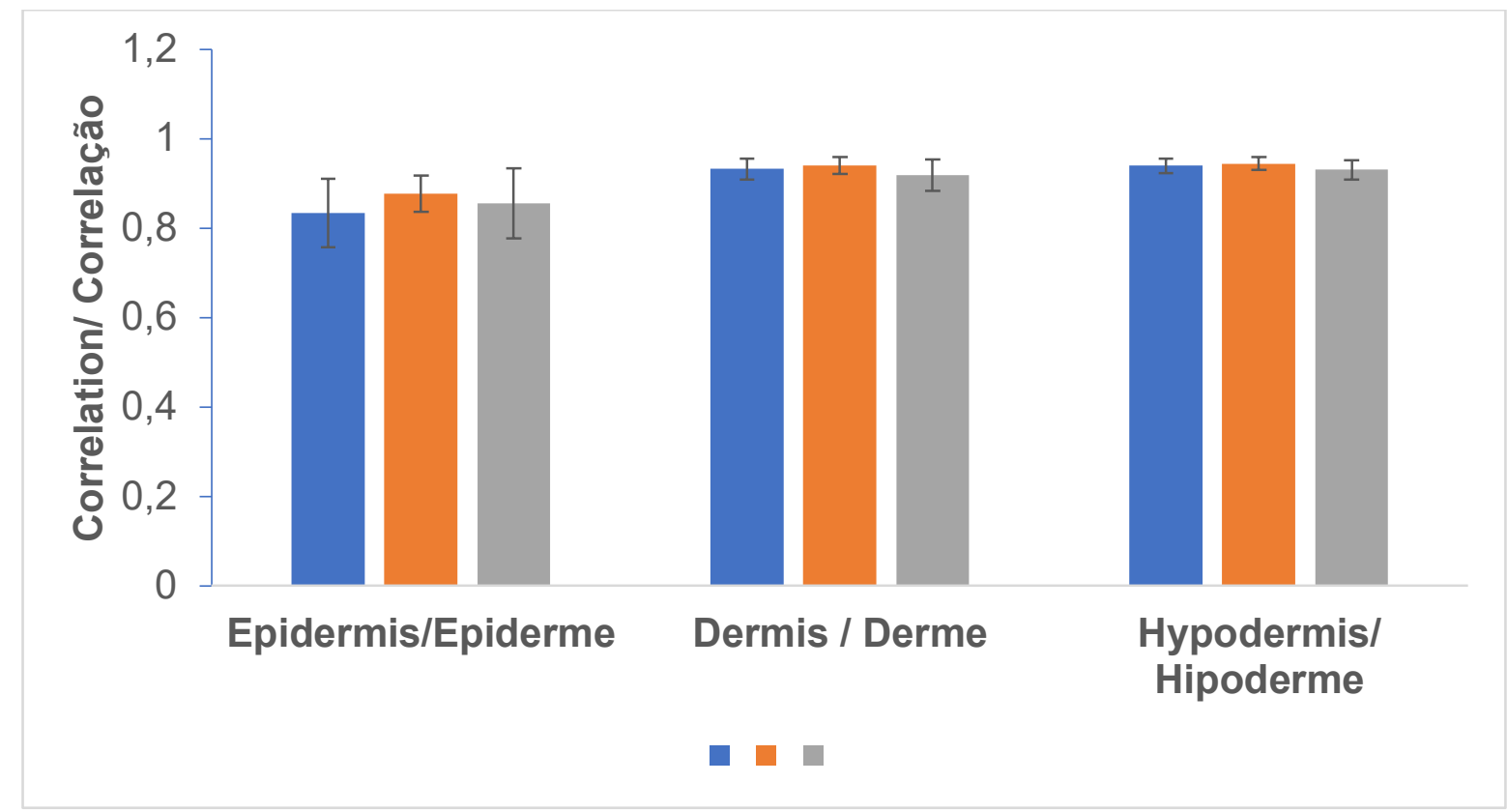

Figure 7/Figura 7 - Correlation analysis of the epidermis, dermis and hypodermis of the non-treated skin, hydrated skin, and erythema (values represent mean $n=6$ and error bars represent standard deviation). Análise de correlação da epiderme, derme e hipoderme de pele não tratada, pele hidratada e com eritema (são representados valores médios $n=6$ enquanto que as barras de erro representam o desvio padrão)

\section{Conclusion}

In this work we suggest the use of TA as a possible approach to address the lack of analytical tools for sonograms which hinders the applicability of ultrasonography in dermatology. We developed a protocol with various skin treatments to test our TA algorithm. Our results show the algorithm developed is appropriate for the analysis of the different layers of the skin and has reproducibility and low variability. Furthermore, we expect this algorithm to be valuable tool to help differentiate the borders of skin layers and structures in the near future.

\section{Acknowledgements}

The authors wish to acknowledge the FCT-IP project UID/DTP/04567/2016 for the funding to carry out this work.

\section{Conflict of interests}

The authors declare that there is no financial or personal relationship that can be understood as representing any potential conflict of interest.

\section{Conclusão}

Neste trabalho, sugerimos o uso da TA como uma possível abordagem para lidar com a falta de ferramentas analíticas para sonogramas que dificultam a aplicabilidade da ultrassonografia na dermatologia. Foi desenvolvido um protocolo com vários tratamentos de pele para testar o algoritmo de TA. Os resultados mostram que o algoritmo desenvolvido é apropriado para a análise das diferentes camadas da pele e tem reprodutibilidade e baixa variabilidade. O algoritmo desenvolvido é uma ferramenta valiosa com potencial para ajudar a diferenciar as fronteiras das camadas e estruturas da pele no futuro próximo.

\section{Agradecimentos}

Os autores gostariam de agradecer ao projeto FID-IP UID / DTP / 04567/2016 pelo financiamento para realizar este trabalho.

\section{Conflito de interesses}

Os autores declaram que não existe uma relação financeira ou pessoal que possa ser entendida como representando um potencial conflito de interesses. 


\section{References/ Referências}

[1] H. Alexander and D. L. Miller, "Determining skin thickness with pulsed ultra sound,” J. Invest. Dermatol., 1979.

[2] A. Åkesson, R. Hesselstrand, A. Scheja, and M. Wildt, "Longitudinal development of skin involvement and reliability of high frequency ultrasound in systemic sclerosis," Ann. Rheum. Dis., 2004.

[3] S. El Gammal et al., "Sonography of the skin at $100 \mathrm{MHz}$ enables in vivo visualization of stratum corneum and viable epidermis in palmar skin and psoriatic plaques," J. Invest. Dermatol., vol. 113, no. 5, pp. 821-829, 1999.

[4] S. Seidenari, "High-frequency sonography combined with image analysis: A noninvasive objective method for skin evaluation and description," Clin. Dermatol., vol. 13, no. 4, pp. 349-359, 1995.

[5] M. H. Schmid-Wendtner and D. Dill-Müller, "Ultrasound Technology in Dermatology," Semin. Cutan. Med. Surg., vol. 27, no. 1, pp. 44-51, 2008

[6] A. Polańska et al., "Comparison between high-frequency ultrasonography (Dermascan C, version 3) and histopathology in atopic dermatitis," Ski. Res. Technol., vol. 19, no. 4, pp. 432-437, 2013.

[7] A. Mandava, P. Ravuri, and R. Konathan, "High-resolution ultrasound imaging of cutaneous lesions," Indian J. Radiol. Imaging, 2013.

[8] A. Caggiati, "Ultrasonography of Skin Changes in Legs with Chronic Venous Disease," Eur. J. Vasc. Endovasc. Surg., 2016.

[9] M. Gutierrez, X. Wortsman, E. Filippucci, R. De Angelis, G. Filosa, and W. Grassi, "High-frequency sonography in the evaluation of psoriasis: Nail and skin involvement," J. Ultrasound Med., 2009.

[10] A. Di Nardo, S. Seidenari, and A. Giannetti, "B-scanning evaluation with image analysis of psoriatic skin,” Exp. Dermatol., vol. 1, no. 3, pp. 121-125, 1992

[11] D. Digiacinto, J. Bagley, and A. M. Goldsbury, "The value of sonography in the assessment of skin cancers and their metastases," J. Diagnostic Med. Sonogr., vol. 32, no. 3, pp. 140-146, 2016.

[12] F. Alfageme Roldán, “Ultrasound Skin Imaging,” Actas Dermosifiliogr., vol. 105, no. 10, pp. 891-899, 2014.

[13] H. Mohafez et al., "Quantitative assessment of wound healing using high-frequency ultrasound image analysis," Ski. Res. Technol., vol. 24, no. 1, pp. $45-53,2018$.

[14] W. Henry, "Texture Analysis Methods for Medical Image Characterisation," in Biomedical Imaging, 2010.

[15] A. S. E. B. El Hassani, M. El Hassouni, R. Jennane, M. Rziza, and E. Lespessailles, "Texture analysis for trabecular bone X-ray images using anisotropic morlet wavelet and Rényi entropy," in Lecture Notes in Computer Science (including subseries Lecture Notes in Artificial Intelligence and Lecture Notes in Bioinformatics), 2012.

[16] A. Kassner and R. E. Thornhill, "Texture analysis: A review of neurologic MR imaging applications," American Journal of Neuroradiology. 2010.

[17] F. Chamming's et al., "Features from Computerized Texture Analysis of Breast Cancers at Pretreatment MR Imaging Are Associated with Response to Neoadjuvant Chemotherapy,” Radiology, 2017.

[18] "World medical association declaration of helsinki: Ethical principles for medical research involving human subjects," J. Korean Med. Assoc., 2014.

[19] K. Hoffmann et al., "20 MHz sonography, colorimetry and image analysis in the evaluation of psoriasis vulgaris," J. Dermatol. Sci., vol. 9, no. 2, pp. $103-110,1995$.

[20] D. A. Perednia, "What dermatologists should know about digital imaging,” J. Am. Acad. Dermatol., vol. 25, no. 1, pp. 89-108, 1991.

[21] D. Dill-Müller and J. Maschke, "Ultrasonography in dermatology," Jddg, vol. 5, no. 8, pp. 689-707, 2007.

[22] E. de O. Barcaui, A. C. P. Carvalho, J. Piñeiro-Maceira, C. B. Barcaui, and H. Moraes, "Study of the skin anatomy with high-frequency (22 MHz) ultrasonographyand histological correlation," Radiol. Bras., vol. 48, no. 5, pp. 324-329, 2015. 